
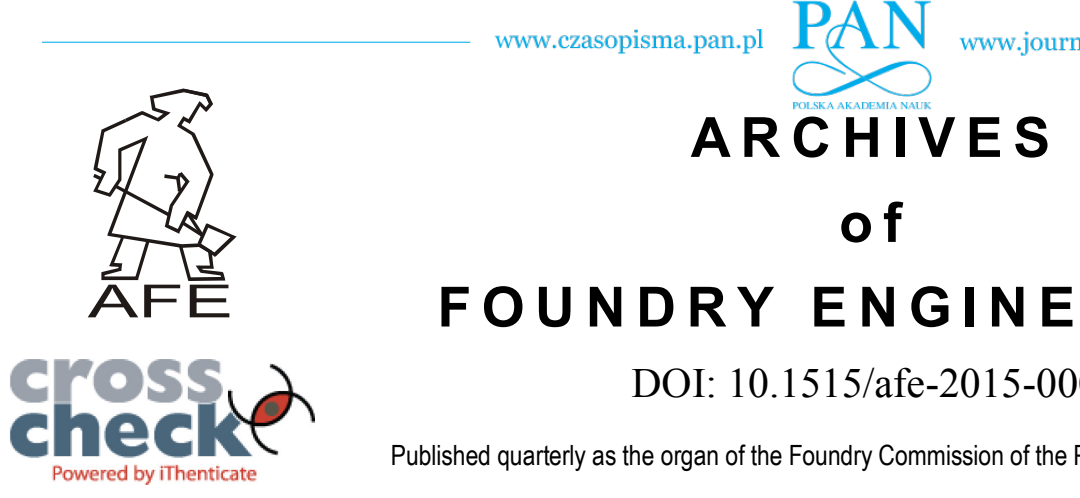

ARCHIVES

\title{
The Mathematical Model of Hydrodynamics and Heat and Mass Transfer at Formation of Steel Ingots and Castings
}

\author{
V.I. Bondarenko, V.V. Bilousov*, F.V. Nedopekin, J.I. Shalapko \\ Faculty of Physics of Nonequilibrium Processes, Metrology and Ecology of Donetsk National University, Ukraine \\ *Corresponding author. E-mail address: v.v.bilousov@gmail.com
}

Received 12.05.2014; accepted in revised form 22.07.2014

\begin{abstract}
The generic mathematical model and computational algorithm considering hydrodynamics, heat and mass transfer processes during casting and forming steel ingots and castings are offered. Usage domains for turbulent, convective and non-convective models are determined depending on ingot geometry and thermal overheating of the poured melt. The expert system is developed, enabling to choose a mathematical model depending on the physical statement of a problem.
\end{abstract}

Keywords: Mathematical model, Numerical modeling, Steel ingot, Turbulent convection, Expert system, Physical statement of problem

\section{Introduction}

During development of process specifications for casting and forming steel ingots and casts, the preliminary explorations are necessary, which allow determining rational hydrodynamic and thermophysical parameters of a product. Mathematical methods are employed for this purpose, as being the most justified while exploring interdependent processes during steel ingot formation. This article is devoted to the selection of a mathematical model and computational algorithm depending on casting type and conditions of a steel ingot formation.

\section{Mathematical model}

The mathematical model is formulated, enabling to research convective heat mass transfer in a melt in the enclosed volume; this model consists of equations of motion, continuity, heat and mass transfer, a gas phase, turbulent kinetic energy $(\mathrm{k})$, its dissipation rate $(\varepsilon)$, and also of the equations for solid phase proportion $(\xi)$ :

$$
\begin{aligned}
& (\vec{V} \nabla) \vec{V}=-\frac{1}{\rho} \nabla P+\nabla\left(v+v_{t}\right) \nabla \vec{V}+\vec{g} \beta\left(T-T_{l}\right) \\
& \frac{\partial\left(r V_{r}\right)}{\partial r}+\frac{\partial\left(r V_{z}\right)}{\partial z}=0
\end{aligned}
$$


$c \rho(\vec{V} \nabla T)=\nabla\left(\lambda+\lambda_{t}\right) \nabla T ;$

$\frac{1}{r} \frac{\partial}{\partial r}\left(r k V_{r}\right)+\frac{\partial k V_{z}}{\partial z}=\frac{1}{r} \frac{\partial}{\partial r}\left(\frac{v+v_{t}}{\sigma_{k}} r \frac{\partial k}{\partial r}\right)+\frac{\partial}{\partial z}\left(\frac{v+v_{t}}{\sigma_{k}} r \frac{\partial k}{\partial z}\right)+G-\varepsilon ;$

$\frac{1}{r} \frac{\partial}{\partial r}\left(r \varepsilon V_{r}\right)+\frac{\partial \varepsilon V_{z}}{\partial z}=\frac{1}{r} \frac{\partial}{\partial r}\left(\frac{v+v_{t}}{\sigma_{\varepsilon}} r \frac{\partial \varepsilon}{\partial r}\right)+\frac{\partial}{\partial z}\left(\frac{v+v_{t}}{\sigma_{\varepsilon}} \frac{\partial \varepsilon}{\partial z}\right)+\frac{C_{1} \varepsilon G}{k}-\frac{C_{2} \varepsilon^{2}}{k} ;$

$\xi(z)=1-\left(1+\frac{c}{W}\left(T_{l}-T_{s}\right)\right)\left[1-\left(\frac{T_{l}-T}{T_{l}-T_{s}}\right)^{2 / 3}\right]+\frac{c}{W}\left(T_{l}-T_{s}\right) ;$

$\frac{\partial C_{\Gamma}}{\partial t}+(\vec{V} \nabla) C_{\Gamma}=0$

where

$G=v_{t}\left[2\left(\frac{\partial V_{r}}{\partial z}\right)^{2}+\left(\frac{\partial V_{z}}{\partial r}\right)^{2}+\left(\frac{V_{r}}{r}\right)^{2}+\left(\frac{\partial V_{r}}{\partial z}+\frac{\partial V_{z}}{\partial r}\right)^{2}\right] ; v_{t}=\frac{C_{\mu} k^{2}}{\varepsilon} ; \mathrm{C}_{\mu}=0,09 ; C_{1}=1,45 ; C_{2}=0,18 ; \sigma_{k}=1,0 ; \sigma_{\varepsilon}=1,0-$

empirical coefficients; $\vec{V}$ - velocity vector, $\mathrm{m} / \mathrm{s} ; V_{r}$ and $V_{z}$-radial and vertical component of speed of liquid, $\mathrm{m} / \mathrm{s} ; t-$ dimensional time; $\rho$ - density, $\mathrm{kg} / \mathrm{m}^{3} ; P$ - pressure, $\mathrm{N} / \mathrm{m}^{2} ; \boldsymbol{V}, v_{t}$ - kinematic and turbulent coefficient of viscosity, $\mathrm{m}^{2} / \mathrm{s} ; \vec{g}$ - acceleration of gravity, $\mathrm{m} / \mathrm{s}^{2} ; T$ - current temperature, ${ }^{\circ} \mathrm{C} ; C$ - heat capacity, $\mathrm{J} /(\mathrm{\kappa g} \cdot \mathrm{K}) ; \lambda, \lambda_{t}=v_{t} / 0,9$-molecular and turbulent coefficient of heat conductivity, $\mathrm{W} /(\mathrm{m} \cdot \mathrm{K}) ; r, z$-current coordinates, on radius and on height, accordingly (cylindrical coordinates), $\mathrm{m}$. The system of the equations (1) - (7) is supplemented with boundary conditions, for $V_{r}, V_{z}, T$; $\xi$ - the fraction of a solid phase which is defined from a rule of the nonequilibrium lever determined, $\beta$ - coefficient of volumetric expansion $1 / \mathrm{K}, C_{\Gamma^{-}}$-gas phase, $W$ - latent heat of crystallization, $\mathrm{J} / \mathrm{kg}$ , $\mathrm{T}_{1}$ and $\mathrm{T}_{\mathrm{s}}$ - liquidus and solidus temperature [3].

The mathematical model is based on the principles of macrocontinuum mechanics of multiphase media and quasiequilibrium theory of a biphase zone. The model considers turbulence, melt gas capture (during a steel mold filling and metal solidification), thermal, concentration and mixed convection. The system of the equations (1) - (7) is supplemented with boundary conditions [3].

\section{Computational algorithm}

The system of the equations (1) - (7) is realized in the variables of the current vorticity function $(\omega-\psi)$, which is the most effective during the transport simulation in flat statement in terms of computer resources saving [3].

The implicit monotonic finite-difference scheme is constructed using the perturbed operator integro-interpolation method, upwind difference method and sweep method. The set of all these methods converts the nonlinear differential equations to a chain of the algebraic ones.

\section{Convective heat and mass transfer in the natural conditions}

The mathematical model allows implementing the following problems.

Problem 3a. Top casting. The implementation of this problem resulted in the following:
- $\quad$ influence of turbulent viscosity promotes reduction of strand penetration depth by $60 \%$ during pouring into the steel mold at melt mass-flow rate of $1000 \mathrm{~kg} / \mathrm{min}$ and overheating $60^{\circ} \mathrm{C}$;

- the zone of the strand active influence occupies $45 \%$ of the melt volume and is localized in the top part of the melt, the zone of thermal convection influence makes $55 \%$ of the steel mold cavity volume;

- $\quad$ turbulence influence results in $10 \%$ acceleration of solid skin growth, in particular in the bottom near-wall area;

- consideration of gas capture and turbulence in aggregate leads to $68 \%$ reduction of strand penetration depth into a melt with the gas phase content of $20 \%$ and to $21 \%$ growth of 'a solid skin' in the steel mold bottom (Fig. 1).

Problem 3b. Bottom casting. Influence of turbulence and a gas phase practically has not affected the height of the immersed strand core and distribution vertical rate components on the steel mold axis, at the same time natural convection influence has increased in the bottom near-wall area. Turbulent viscosity increases the solid skin thickness in the steel mold bottom by $25 \%$, whereas cumulative influence of turbulent viscosity and a gas phase provides $40 \%$ increase in the solid skin thickness. It has been established, that consideration of turbulence is necessary at following values of ReGr*: for the top casting - at $8.910^{12}$, and for the bottom casting - at $3.810^{13}$, where $\mathrm{Gr}^{*}=$ $\mathrm{g} \Delta \mathrm{Tx}_{\mathrm{m}}^{3} \beta / v^{2}, \mathrm{x}_{\text {пр }}$ - the effective size of $\mathrm{n}$ ingot (ingot volume-to surface area ratio). The selection of $\mathrm{x}_{\text {пр }}$ allows considering various correlations of a steel ingot geometrical sizes. 

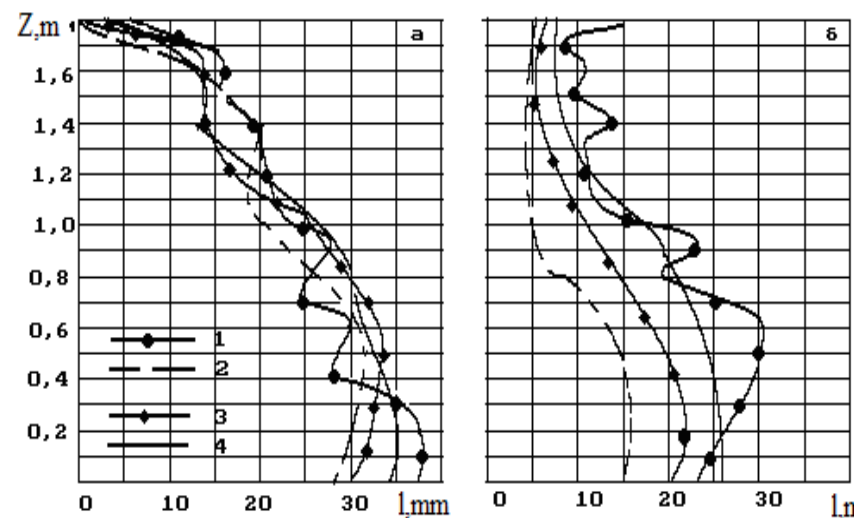

Fig. 1. Solid skin thickness against height of 15.3 ton ingot with bottom casting (a) and top casting (б); curve 1 shows the experimental results, curve 2 represents calculation without turbulence considered, curve 3 - with regard to turbulence, curve 4 - with regard to turbulence and a gas phase

Problem 3c. Transport processes are calculated at the steel ingot solidification in conditions of turbulent heat concentrationinduced convection. It is revealed that:

- The melt turbulent characteristics are most significant within the first 4-5 minutes, in further their role sharply falls;

- $\quad$ It is required to take convection into account at $\mathrm{Ra}^{*}>1.5$ $10^{6}$, and to consider turbulence at $\mathrm{Ra}^{*}>510^{8}$.

The diagram of selecting turbulent, laminar and nonconvection model of ingot formation (Fig. 2) is constructed. The diagram allows installing the applicability domain borders for the system of the equations (1) - (8) from $\mathrm{Ra}^{*}$ number $\left(\mathrm{x}_{\text {пр }}, \Delta \mathrm{T}\right)$. At $\mathrm{Ra}^{*}$ value $>5.410^{8}$ turbulent heat and mass transfer is implemented, which is described by the system of the equations (1)-(8). At $10^{6}<\mathrm{Ra}^{*}<5.410^{8}$ flow regime becomes laminar and is described by the system of the equations excluding turbulence. At $\mathrm{Ra}^{*}<10^{6}$ convective transfer in the solidifying melt may be neglected.

The time of the intensive influence of natural laminar and turbulent convective heat exchange on hydrodynamic and heat and mass transfer processes in the solidifying ingot is determined.

In order to determine the time of a convective model application, the solidification calculation results for 12 options were processed (ranging from 2.7 to 420 tons at overheating $\Delta \mathrm{T}=60^{\circ} \mathrm{C}$ ) and the following formula is obtained:

$\mathrm{Fo}_{\mathrm{K}}=5.39 \mathrm{Ra} * 10^{-0.12}$

For example, for 24 ton carbon steel ingot Ст. $0.8\left(\mathrm{x}_{\text {пр }}=0.32 \mathrm{~m}\right.$ and $\Delta \mathrm{T}=60^{\circ} \mathrm{C}$ ) value of $\mathrm{Ra}^{*}$ number $=6.110^{8}$. Substituting the $\mathrm{Ra}^{*}$ value in the formula (8), we obtain $\mathrm{Fo}_{\mathrm{K}}=5.2510^{-2}$. We determine the dimensional time, at which it is recommended to consider natural convection influence $\left(\mathrm{t}_{\mathrm{K}}=\mathrm{Fo}_{\mathrm{K}} \mathrm{x}_{\mathrm{np}} / \mathrm{a}\right)$, and which for the specified steel is equal $97.1 \mathrm{~min}$. The further consideration of convection is inexpedient since by virtue of small stirring rates it does not influence the full time of an ingot solidification and the configuration of 'solid skin' [1].

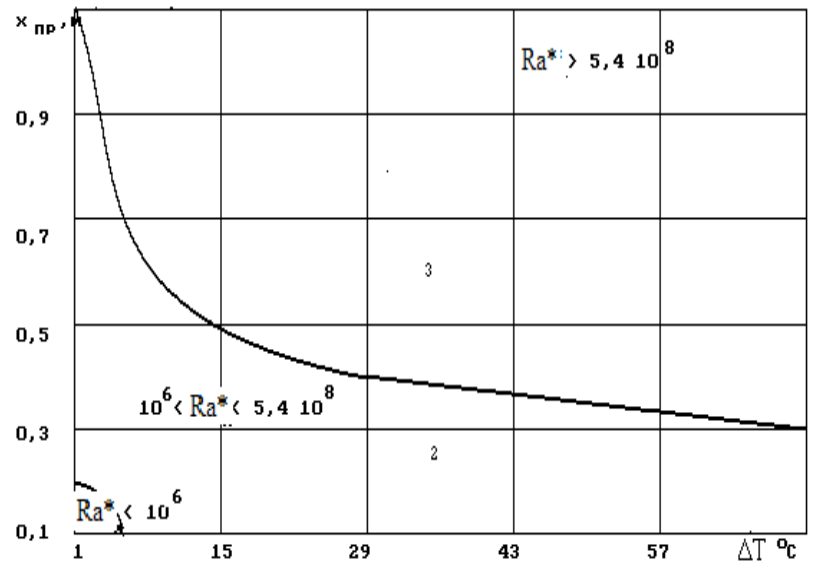

Fig. 2. Diagram of a mathematical model selection depending on the effective size and overheating: 1 - non convective model, 2 laminar convection, 3 - turbulent convection

To determine time intervals of convection existence in the turbulent regime $20 \ldots 420$-ton ingots have been explored at $\Delta \mathrm{T}$ $=60^{\circ} \mathrm{C}$ and dependence is also constructed:

$$
\mathrm{Fo}_{\mathrm{t}}=0,208 \mathrm{Ra} * 10^{-0,068} .
$$

The technique for determination of rational temporary borders of a turbulent model application while calculating hydrodynamic and thermophysical processes in a ingot is similar to the foregoing procedure for consideration of convective model. For a 24-ton ingot the physical time of turbulent convection existence makes $t_{t}$ $=19.6 \mathrm{~min}$.

\section{Expert system}

To specify a mathematical model the expert system for input parameters selection is used:

1. The ingot geometry;

2. The ingot tonnage;

3. Casting type;

4. Speed of melting in the steel mold during ingot casting

The listed parameters are names of fields in the table of a database where each record is considered as a set of key parameters of a master schedule $[4,5,6]$.

The following parameters are selected as the target ones:

1. Poisson equation iteration parameter

2. Turbulence sample

3. Problem statement grid

4. Time increment

5. Ingot solidification time

Decision-making on each of the listed parameters is performed consistently. Fig. 3 shows the diagram of influence (acyclic columns) reflecting dependence between the key parameters. It is visible that there are dependences between the target parameters, as well. 


\section{Conclusions}

The generic mathematical model and computational algorithm considering hydrodynamics, heat and mass transfer processes during casting and forming steel ingots and castings are presented.

Usage domains for turbulent, convective and non-convective models are shown depending on ingot geometry and thermal overheating of the poured melt.
The expert system is developed, enabling to choose a mathematical model depending on the physical statement of a problem.

The presented complex allows accelerating considerably the software development for simulating complex nonlinear processes of steel ingots and casts formation. Thus, it becomes possible to reduce essentially the debugging process and to confirm convergence and stability of the software and the computational algorithm.

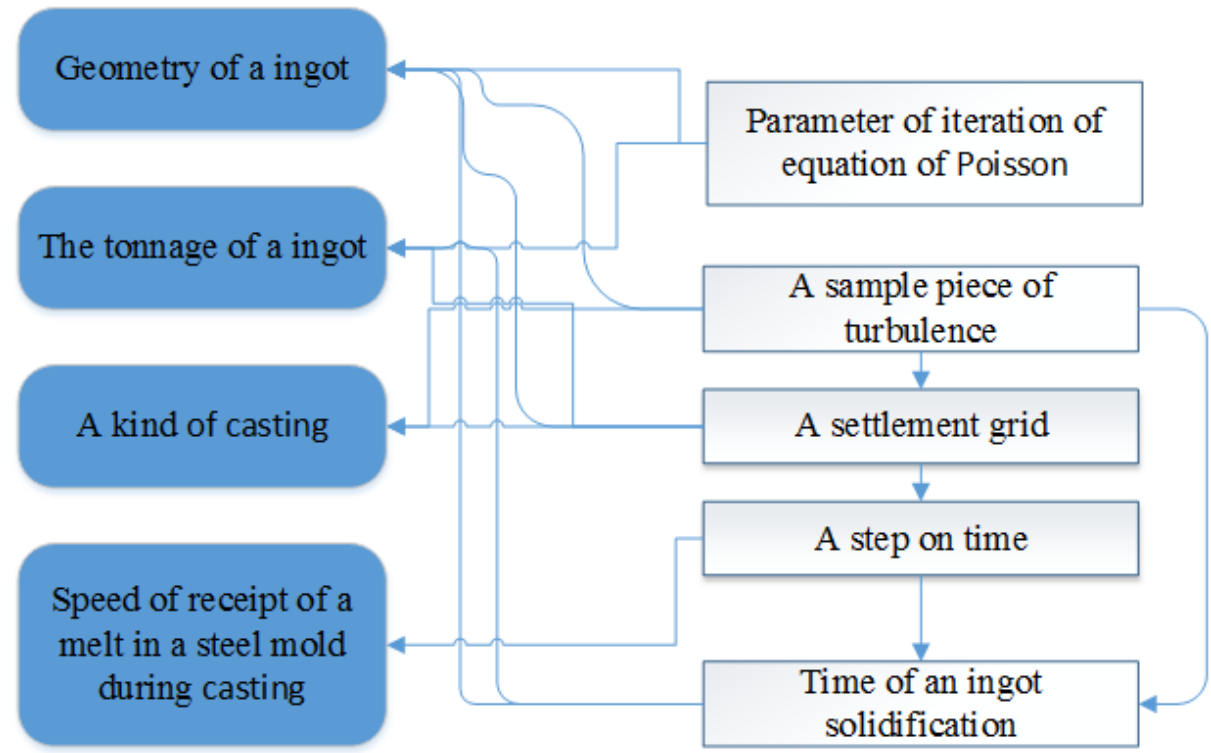

Fig. 3. Diagram of influence of parameters

\section{References}

[1] Белоусов, В.В., Недопекин, Ф.В. Кондратенко В.М. и др. (2005). Затвердевание металлических композиций: производство и моделирование - Донецк ООО «ЮгоВосток», ЛТД, - 231с.

[2] Бабанин А.Я., Паренчук В.В., Белоусов В.В. и др. (2008). Ковшевая обработка литейных расплавов порошковыми лентами и проволоками - Донецк ООО «Юго-Восток», ЛТД, - 140с.

[3] Недопекин, Ф.В., Хрычиков, В.Е., Белоусов, В.В. и др. (2009). Затвердевание металлов и металлических композиций. Наукова думка, Киев. 412 с.
[4] Джексон, П. (2001). Введение в экспертные системы. 3-е изд. - М.: Вильямс, - 624c.

[5] Джарратано, Д. (2006). Гари Райли «Экспертные системы: принципы разработки и программирование»: Пер. с англ. - М. : Издательский дом «Вильямс», - 1152 стр.

[6] V.V.Bilousov, V.I. Bondarenko (2011). Computer modeling of wheel steel ingots formation Scientific basis of modern technologies: experience and prospects. Jaremche.-p.147-154 